\title{
Characterisation of Pinotage Wine During Maturation on Different Oak Products
}

D. de Beer $^{1 *}$, E. Joubert ${ }^{1,2}$, J. Marais ${ }^{2}$, W. du Toit ${ }^{3}$, B. Fourie ${ }^{3}$ and M. Manley ${ }^{1}$

(1) Department of Food Science, Stellenbosch University, Private Bag X1, 7602 Matieland (Stellenbosch), South Africa.

(2) Post-Harvest and Wine Technology Division, ARC Infruitec-Nietvoorbij, Private Bag X5026, 7599 Stellenbosch, South Africa.

(3) Department of Enology and Viticulture, Stellenbosch University, Private Bag X1, 7602 Matieland (Stellenbosch), South Africa.

Submitted for publication: October 2007

Accepted for publication: January 2008

Key words: ABTS; maturation; colour; Pinotage; phenolic compounds; antioxidants

\begin{abstract}
The effect of oak contact on the phenolic composition, total antioxidant capacity (TAC) and colour of Pinotage wines was investigated during maturation. Oak maturation included traditional treatments, such as new, second-fill and third-fill barrels, as well as alternative treatments (oak chips, staves, extract and dust) applied in old barrels over a period of 28 weeks. Oak maturation using traditional and alternative treatments improved the objective colour of Pinotage wine by decreasing the $L$ * value. Losses in TAC caused by decreased concentrations of monomeric phenolic compounds (most anthocyanins, flavan-3-ols, flavonols and hydroxycinnamic acids) during oak maturation were negated by increased concentrations of gallic acid and the formation of new oligomeric and polymeric pigments. Wine maturation in stainless steel containers also resulted in a decrease in anthocyanin content. The decrease in phenolic acid content for wines matured in stainless steel was less pronounced, while their flavan-3-ol content remained stable. The new-barrel treatment had the most pronounced effect on all parameters. Oak maturation can be used for the production of Pinotage wine when the retention of TAC is a high priority.
\end{abstract}

Maturation is an important phase in the production of high-quality red wines and leads to increased stability of the colour and improved taste and quality. Oak barrels are generally used but, recently, alternative oak sources used in old barrels or stainless steel tanks, and/or oxygenation, have increased the options available to the winemaker. Alternative oak treatments used by winemakers include chips, staves and extracts. By introducing large quantities of oak chips or staves for a short time, the oak maturation process is thought to be accelerated (Del Alamo Sanza et al., 2004). However, alternative oak treatments can also be used to simulate normal barrel maturation by introducing them into used barrels at lower dosages.

The main compounds extracted from oak during maturation are cinnamic and benzoic acid derivatives from the tannins that are hydrolysable by oak wood, as well as furaldehydes from sugar degradation during the process of toasting the oak (Laszalavik et al., 1995; Kadim \& Mannheim, 1999; Del Alamo Sanza et al., 2004). Other important changes in phenolic composition during maturation in oak barrels involve condensation reactions of anthocyanins with flavan-3-ols to form oligomeric and polymeric phenolic compounds, leading to stabilised colour (Timberlake \& Bridle, 1976; Singleton, 1987). Ingress of small amounts of oxygen contributes to oxidative polymerisation during maturation in oak barrels (Singleton, 1987). In the presence of oxygen, ethanol is oxidised to acetaldehyde (Wildenradt \& Singleton, 1974), which contributes to the formation of ethyl-linked anthocyanin-fl- avan-3-ol condensation products. Oxidation of ellagitannins from oak wood produces peroxides, which in turn oxidise ethanol to acetaldehyde (Vivas \& Glories, 1996). Therefore, acetaldehydemediated condensation reactions involving anthocyanins and flavan-3-ols are especially important. The evolution of wine redox potential during maturation in oak barrels, as well as in stainless steel tanks in the presence of oak chips and staves, was reported by Del Álamo et al. (2006). An initial increase in redox potential was observed from zero to three months of maturation, with a subsequent decrease up to the end of maturation (11 months' total maturation time). Dávalos et al. (2004) found a higher ORAC (oxygen radical absorbance capacity) in oak-aged wines than in bottled-aged wines of the same vintage and variety.

Since oak maturation affects the phenolic composition of the wine, especially with regard to polymerisation, it is possible that its total antioxidant capacity (TAC) will also be affected. A change in TAC during maturation is most likely to be negative. Some reactions of phenolic compounds during pre-bottling maturation are expected to be similar to those that occur during bottle maturation, which has been shown to decrease the TAC of Pinotage and Cabernet Sauvignon wines (De Beer et al., 2005). In order to produce wines with optimal TAC, the effect of oak maturation and oxygenation on their TAC should be taken into account. The aim of this study was to investigate the effect of traditional and alternative oak products on the phenolic composition, colour and TAC of Pinotage wines during maturation.

"Corresponding author: e-mail: DBeerD@arc.agric.za

Acknowledgements: The authors wish to thank Frikkie Calitz of the ARC Biometry Unit, for statistical analysis of the data; the Wine Industry Network of Expertise and Technology (Winetech) and the Technology and Human Resources for Industry Programme (THRIP) of the Department of Trade and Industry (grant 2621), for funding, and the National Research Foundation (NRF) of South Africa, for a student bursary for D. de Beer. 


\section{MATERIALS AND METHODS}

\section{Oak maturation treatments}

A Pinotage wine was produced from grapes (Vitis vinifera L. cv. Pinotage) harvested at $-24^{\circ}$ Brix at Nietvoorbij (Stellenbosch, South Africa) in February 2002. Winemaking was carried out according to standard commercial winemaking procedures at $15^{\circ} \mathrm{C}$ in a closed stainless steel fermenter at Distell (Stellenbosch, South Africa). The total must volume was $9000 \mathrm{~L}$. After malolactic fermentation, bulk filtration was performed and the free $\mathrm{SO}_{2}$ was adjusted to $35 \mathrm{mg} / \mathrm{L}$ before transference to oak barrels for maturation. Free $\mathrm{SO}_{2}$ concentrations were maintained at $35 \mathrm{mg} / \mathrm{L}$ during the oak maturation period.

Treatments consisted of new barrels, second-fill barrels, thirdfill barrels, as well as old barrels (fifth fill) with oak chips (3 to 10 mm shavings at $6 \mathrm{~g} / \mathrm{L})$, oak staves ( $30 \times 5 \times 100 \mathrm{~mm}$ at $6 \mathrm{~g} / \mathrm{L})$, oak extract (freeze-dried French oak extract at $110 \mathrm{mg} / \mathrm{L}$ ) supplied by Radoux Cooperage (Stellenbosch, South Africa) and oak dust (granular American oak dust at $6 \mathrm{~g} / \mathrm{L}$ ) supplied by African Cork Supplies (Stellenbosch, South Africa). All additions were made according to the manufacturers' recommendations. The barrels (225 L) were supplied by Radoux Cooperage. The new and old barrels, oak chips and oak staves were produced from French oak. Wine was matured in triplicate for each treatment for 28 weeks from May 2002, except the for new-barrel treatment, which was done in duplicate. Wine was also stored in triplicate in $20 \mathrm{~L}$ stainless steel containers. A sample $(\sim 200 \mathrm{~mL})$ was taken from each barrel at zero, six, 15 and 28 weeks. The sample taken at zero weeks was considered to be the non-matured control, i.e. control wine ( 0 weeks), while the samples taken from the stainless steel containers after 28 weeks were considered the stainless steel matured control, i.e. control wine (SS). The original wine, stored in stainless steel tanks, was used to fill up the barrels once a month to compensate for the volume of wine loss due to evaporation and during sampling. Directly after sampling, aliquots of each sample were frozen at $-20^{\circ} \mathrm{C}$ to prevent further phenolic changes until the analyses could be carried out. Samples were analysed immediately after defrosting.

\section{Chemicals and phenolic reference standards}

2,2'-Azino-di-(3-ethylbenzo-thialozine-sulphonic acid) (ABTS) was obtained from Boehringer Mannheim GmbH (Mannheim, Germany), and HPLC-grade acetonitrile and phosphoric acid were obtained from Riedel-de Häen (Seelze, Germany) and Fluka (Buchs, Switzerland) respectively. 6-Hydroxy-2,5,7,8-tetra-methylchroman-2-carboxylic acid (Trolox) was obtained from Aldrich Chemical Co. (Gillingham, UK). Phenolic reference standards included gallic acid, (+)-catechin, (-)-epicatechin, quercetin-3galactoside and quercetin-3-rhamnoside from Sigma (St Louis, MO); caffeoyltartaric acid from Chromadex (Santa Ana, CA); caffeic acid, quercetin and kaempferol from Fluka; procyanidin B1, quercetin-3-glucoside (glc) and myricetin from Extrasynthese (Genay, France); and delphinidin-3-glc, peonidin-3-glc, petunidin-3-glc and malvidin-3-glc from Polyphenols AS (Sandnes, Norway). Water used in the experiments was purified and de-ionised with a Modulab water purification system (Separations, Cape Town, South Africa), except for that used in the preparation of the HPLC mobile phases, where the de-ionised water was treated further using a Milli-Q académic water purifier (Millipore, USA).

\section{Spectrophotometric analysis of phenolic content}

The total phenol content was determined in triplicate using the Folin-Ciocalteu assay (Singleton \& Rossi, 1965).

\section{HPLC analysis of phenolic composition}

Individual phenolic compounds, as well as coloured and non-coloured polymers detected at 520 and $280 \mathrm{~nm}$ respectively, were quantified in duplicate using an HPLC method (Peng et al., 2002) modified and described by De Beer et al. (2006). The polymers included polymeric phenolic compounds with five or more subunits, with the coloured polymers consisting of anthocyanins and flavan-3-ols, and the non-coloured polymers consisting only of flavan-3-ols.

\section{ABTS radical cation scavenging assay}

The total antioxidant capacity (TAC) of the wines was measured $\left(\mathrm{TAC}_{\mathrm{M}}\right.$ ) in triplicate using the $\mathrm{ABTS}^{++}$scavenging assay (Re et al., 1999). The content of individual phenolic compounds, measured by HPLC, and their experimental TEAC values (reported in De Beer et al., 2006) were used to calculate the theoretical TAC $\left(\mathrm{TAC}_{\mathrm{CAL}}\right)$. The remaining TAC $\left(\mathrm{TAC}_{\mathrm{R}}\right)$ is the difference between $\mathrm{TAC}_{\mathrm{M}}$ and $\mathrm{TAC}_{\mathrm{CAL}}$. The analysis and calculations were carried out as described in De Beer et al. (2006).

\section{Objective colour parameters}

A Colorgard System 2000 Colorimeter (BYK-Gardner, Geretsried, Germany) was used to obtain the objective colour parameters of the undiluted Pinotage wines in transmittance mode with an optical cell with a fixed path length of $5 \mathrm{~mm}$. The colorimeter was calibrated before use with a non-diffusing black reflectance standard (BYKGardner, Geretsried, Germany). Objective colour measurements were taken $<1 \mathrm{~h}$ after opening a wine bottle to minimise colour changes. The CIELab parameters, namely $a^{*}$ (red/green chromaticity), $b^{*}$ (yellow/blue chromaticity) and $L^{*}$ (lightness), were measured using the CIE 1931 standard colorimetric observer under illuminant $\mathrm{C}$ (geometry is $45^{\circ}$ illumination and $0^{\circ}$ viewing). The $h^{*}$ (hue angle; ${ }^{\circ}$ ) and $C^{*}$ (chroma) were calculated as follows:

$$
\begin{aligned}
& h^{*}=\tan ^{-1}\left(b^{*} / a^{*}\right) \\
& c^{*}=\left[\left(a^{*}\right) 2+\left(b^{*}\right)^{2}\right]^{1 / 2}
\end{aligned}
$$

Names for hues based on the $\mathrm{h}^{*}$ values were adapted from Gonnet (1999): hue angle values of $0^{\circ}, 7.5^{\circ}, 15^{\circ}, 22.5^{\circ}, 30^{\circ}, 37.5^{\circ}$ and $45^{\circ}$ correspond to magenta, red-magenta, magenta-red, red, orange-red, red-orange and orange respectively.

\section{Statistical analysis}

One-way analysis of variance was performed on the means for the triplicate or duplicate samples of each oak maturation and time combination to determine whether significant differences occurred. The Student $t$-LSD test $(\mathrm{P}<0.05)$ was used to determine the statistical differences between means. Canonical discriminant analysis with forward step-wise variable selection was used to differentiate between treatments and time-point on the basis of phenolic composition, antioxidant activity and objective colour measurements. All the statistical analyses were done using the SAS version 8 software package (SAS Institute Inc., Cary, NC).

\section{RESULTS}

\section{Phenolic composition}

Maturation of Pinotage wine in stainless steel containers for 28 weeks caused a significant decrease in the content of all the individual monomeric anthocyanins (Table 1), except for vitisin 
TABLE 1

Effect of oak maturation on the anthocyanin content ${ }^{\text {a }}$ of Pinotage wines.

\begin{tabular}{|c|c|c|c|c|c|c|}
\hline & & Dp-3-glc & Pt-3-glc & Pn-3-glc & Mv-3-glc & Dp-3-glc-ac ${ }^{b}$ \\
\hline Control & 0 weeks & $16.31 \mathrm{a}^{\mathrm{e}}$ & $19.57 \mathrm{abc}$ & $9.33 \mathrm{abc}$ & $191.09 \mathrm{a}$ & $5.66 \mathrm{abc}$ \\
\hline \multirow[t]{3}{*}{ Stainless steel } & 6 weeks & $16.49 \mathrm{a}$ & $19.57 \mathrm{abc}$ & 8.99 abcde & $180.92 \mathrm{abc}$ & 5.23 abcde \\
\hline & 15 weeks & $15.69 \mathrm{ab}$ & $18.24 \mathrm{abcd}$ & 8.44 abcdef & $166.22 \mathrm{e}$ & 5.51 abcde \\
\hline & 28 weeks & $9.04 \mathrm{~g}$ & $11.53 \mathrm{i}$ & $4.45 \mathrm{i}$ & $117.66 \mathrm{~h}$ & $1.95 \mathrm{~g}$ \\
\hline \multirow[t]{3}{*}{ New barrels } & 6 weeks & $15.95 \mathrm{a}$ & $19.70 \mathrm{abc}$ & $9.20 \mathrm{abcd}$ & 175.22 bcde & 4.94 abcdef \\
\hline & 15 weeks & 13.73 bcde & $17.20 \mathrm{defg}$ & 7.49 cdefgh & $151.74 \mathrm{f}$ & 4.33 abcdef \\
\hline & 28 weeks & $10.65 \mathrm{fg}$ & $13.80 \mathrm{~h}$ & $5.66 \mathrm{hi}$ & $119.87 \mathrm{~h}$ & $2.72 \mathrm{fg}$ \\
\hline \multirow[t]{3}{*}{ Second-fill barrels } & 6 weeks & $15.65 \mathrm{ab}$ & $19.15 \mathrm{abcd}$ & $9.34 \mathrm{abc}$ & $181.34 \mathrm{abc}$ & 4.66 abcdef \\
\hline & 15 weeks & $14.83 \mathrm{abcd}$ & $17.67 \mathrm{cdef}$ & 7.98 abcdefg & $163.94 \mathrm{e}$ & 4.72 abcdef \\
\hline & 28 weeks & 12.52 ef & $14.95 \mathrm{~h}$ & 7.5 bcdefgh & $138.30 \mathrm{~g}$ & $3.81 \mathrm{cde}$ \\
\hline \multirow[t]{3}{*}{ Third-fill barrels } & 6 weeks & $16.55 \mathrm{a}$ & $19.57 \mathrm{abc}$ & $9.72 \mathrm{a}$ & $182.84 \mathrm{ab}$ & $5.61 \mathrm{abcd}$ \\
\hline & 15 weeks & $15.64 \mathrm{ab}$ & $18.35 \mathrm{abcd}$ & 8.33 abcdefg & 170.42 cde & 4.95 abcdef \\
\hline & 28 weeks & $13.28 \mathrm{cde}$ & $15.87 \mathrm{efgh}$ & 7.09 efgh & $149.30 \mathrm{fg}$ & $3.37 \mathrm{defg}$ \\
\hline \multirow[t]{3}{*}{ Chips } & 6 weeks & $16.66 \mathrm{a}$ & $19.86 \mathrm{a}$ & $9.44 \mathrm{ab}$ & $181.42 \mathrm{abc}$ & $6.28 \mathrm{ab}$ \\
\hline & 15 weeks & $15.03 \mathrm{abc}$ & 17.90 abcdef & 8.19 abcdefg & $164.56 \mathrm{e}$ & 4.98 abcdef \\
\hline & 28 weeks & $12.65 \mathrm{def}$ & $15.13 \mathrm{gh}$ & $6.76 \mathrm{fgh}$ & $141.78 \mathrm{fg}$ & 3.62 cdefg \\
\hline \multirow[t]{3}{*}{ Staves } & 6 weeks & $16.08 \mathrm{a}$ & $19.87 \mathrm{a}$ & $9.11 \mathrm{abcd}$ & $178.28 \mathrm{bcd}$ & 4.58 abcdef \\
\hline & 15 weeks & $14.99 \mathrm{abc}$ & $18.36 \mathrm{abcd}$ & 8.02 abcdefg & $167.95 \mathrm{def}$ & 4.59 abdef \\
\hline & 28 weeks & $15.00 \mathrm{abc}$ & $18.66 \mathrm{abcd}$ & 8.10 abcdefg & 173.71 bcde & 4.01 cdefg \\
\hline \multirow[t]{3}{*}{ Oak extract } & 6 weeks & $16.77 \mathrm{a}$ & $19.81 \mathrm{ab}$ & $9.32 \mathrm{abc}$ & $183.07 \mathrm{ab}$ & $6.44 \mathrm{a}$ \\
\hline & 15 weeks & $14.87 \mathrm{abc}$ & 17.94 abcde & 8.66 abcdef & 172.79 bcde & 5.51 abcde \\
\hline & 28 weeks & 12.24 ef & $14.86 \mathrm{~h}$ & $6.45 \mathrm{gh}$ & $144.02 \mathrm{fg}$ & 3.30 efg \\
\hline \multirow[t]{3}{*}{ Oak dust } & 6 weeks & $16.60 \mathrm{a}$ & $19.67 \mathrm{abc}$ & $9.40 \mathrm{ab}$ & $180.84 \mathrm{abc}$ & $5.70 \mathrm{abc}$ \\
\hline & 15 weeks & $14.75 \mathrm{abcd}$ & 17.72 bcdef & 8.63 abcdef & $167.68 \mathrm{de}$ & 4.03 bcdefg \\
\hline & 28 weeks & $13.34 \mathrm{cde}$ & $15.83 \mathrm{fgh}$ & 7.39 defgh & $146.26 \mathrm{fg}$ & 4.06 bcdefg \\
\hline \multirow[t]{5}{*}{ ANOVA } & LSD & 2.20 & 2.09 & 1.94 & 11.42 & 2.27 \\
\hline & Oak & 0.1525 & 0.0600 & 0.6988 & $<0.0001$ & 0.7757 \\
\hline & Time & $<0.0001$ & $<0.0001$ & $<0.0001$ & $<0.0001$ & 0.0001 \\
\hline & Interaction & 0.5697 & 0.2928 & 0.8767 & 0.0001 & 0.8826 \\
\hline & & Pt-3-glc-ac ${ }^{b}$ & Pn-3-glc-ac ${ }^{b}$ & Mv-3-glc-ac ${ }^{b}$ & Mv-3-glc-coum ${ }^{b}$ & MA (HPLC) ${ }^{\mathrm{c}}$ \\
\hline Control & 0 weeks & $5.00 \mathrm{ab}$ & $4.45 \mathrm{abc}^{\mathrm{e}}$ & $55.11 \mathrm{a}$ & $20.31 \mathrm{a}$ & $330.63 \mathrm{a}$ \\
\hline \multirow[t]{3}{*}{ Stainless steel } & 6 weeks & $4.82 \mathrm{ab}$ & $4.52 \mathrm{abc}$ & $54.11 \mathrm{ab}$ & $20.02 \mathrm{a}$ & $318.74 \mathrm{abc}$ \\
\hline & 15 weeks & $4.46 \mathrm{abc}$ & $4.05 \mathrm{abcd}$ & 49.31 defgh & $18.95 \mathrm{abc}$ & $294.84 \mathrm{cde}$ \\
\hline & 28 weeks & $1.93 \mathrm{~d}$ & $1.24 \mathrm{e}$ & $32.81 \mathrm{k}$ & $9.89 \mathrm{~h}$ & $191.26 \mathrm{i}$ \\
\hline \multirow[t]{3}{*}{ New barrels } & 6 weeks & $4.93 \mathrm{ab}$ & $5.01 \mathrm{a}$ & 52.71 abcdefg & $19.72 \mathrm{ab}$ & 311.43 abcde \\
\hline & 15 weeks & $3.61 \mathrm{abcd}$ & $3.63 \mathrm{abcd}$ & $45.24 \mathrm{hi}$ & $14.69 \mathrm{efg}$ & $265.11 \mathrm{fgh}$ \\
\hline & 28 weeks & $2.46 \mathrm{~cd}$ & $2.61 \mathrm{de}$ & $35.34 \mathrm{k}$ & $10.81 \mathrm{~h}$ & $241.18 \mathrm{i}$ \\
\hline \multirow[t]{3}{*}{ Second-fill barrels } & 6 weeks & $4.29 \mathrm{abc}$ & $4.73 \mathrm{ab}$ & 53.43 abcde & $19.36 \mathrm{ab}$ & $315.38 \mathrm{abcd}$ \\
\hline & 15 weeks & $3.65 \mathrm{abcd}$ & $3.79 \mathrm{abcd}$ & $48.61 \mathrm{gh}$ & $16.50 \mathrm{cdef}$ & $284.99 \mathrm{efg}$ \\
\hline & 28 weeks & $2.99 \mathrm{bcd}$ & $3.30 \mathrm{bcd}$ & $40.27 \mathrm{j}$ & $14.23 \mathrm{fg}$ & $241.18 \mathrm{~h}$ \\
\hline \multirow[t]{3}{*}{ Third-fill barrels } & 6 weeks & $5.23 \mathrm{a}$ & $4.80 \mathrm{ab}$ & 53.23 abcdef & $19.46 \mathrm{ab}$ & $321.97 \mathrm{abc}$ \\
\hline & 15 weeks & $3.93 \mathrm{abcd}$ & $3.88 \mathrm{abcd}$ & 50.15 bcdefg & $18.64 \mathrm{abc}$ & 297.90 bcde \\
\hline & 28 weeks & $4.08 \mathrm{abcd}$ & $3.06 \mathrm{~cd}$ & $42.96 \mathrm{ij}$ & $15.53 \mathrm{defg}$ & $257.24 \mathrm{gh}$ \\
\hline \multirow[t]{3}{*}{ Chips } & 6 weeks & $5.21 \mathrm{ab}$ & $4.83 \mathrm{ab}$ & 53.45 abcde & $19.77 \mathrm{ab}$ & $321.32 \mathrm{abc}$ \\
\hline & 15 weeks & $4.25 \mathrm{abcd}$ & $3.83 \mathrm{abcd}$ & $49.01 \mathrm{fgh}$ & 17.24 bcde & $288.54 \mathrm{def}$ \\
\hline & 28 weeks & $3.95 \mathrm{abcd}$ & $2.96 \mathrm{~cd}$ & $41.06 \mathrm{ij}$ & $13.69 \mathrm{~g}$ & $244.53 \mathrm{~h}$ \\
\hline \multirow[t]{3}{*}{ Staves } & 6 weeks & $4.19 \mathrm{abcd}$ & $4.70 \mathrm{ab}$ & $53.52 \mathrm{abcd}$ & $18.98 \mathrm{abc}$ & 313.40 abcde \\
\hline & 15 weeks & $3.30 \mathrm{abcd}$ & $3.63 \mathrm{abcd}$ & 49.22 efgh & 17.22 bcde & $290.28 \mathrm{def}$ \\
\hline & 28 weeks & $3.29 \mathrm{abcd}$ & $3.47 \mathrm{abcd}$ & $49.81 \mathrm{cdefg}$ & $16.68 \mathrm{cdef}$ & $295.61 \mathrm{cde}$ \\
\hline \multirow[t]{3}{*}{ Oak extract } & 6 weeks & $5.46 \mathrm{a}$ & $4.74 \mathrm{ab}$ & $54.29 \mathrm{ab}$ & $20.10 \mathrm{a}$ & $324.40 \mathrm{ab}$ \\
\hline & 15 weeks & $4.29 \mathrm{abc}$ & $3.59 \mathrm{abcd}$ & $49.09 \mathrm{gh}$ & $17.94 \mathrm{abcd}$ & 297.89 bcde \\
\hline & 28 weeks & $3.67 \mathrm{abcd}$ & $2.51 \mathrm{de}$ & $40.96 \mathrm{j}$ & $13.66 \mathrm{~g}$ & $243.65 \mathrm{~h}$ \\
\hline Oak dust & 6 weeks & $5.23 \mathrm{ab}$ & $5.00 \mathrm{a}$ & $53.90 \mathrm{abc}$ & $19.05 \mathrm{abc}$ & $320.02 \mathrm{abc}$ \\
\hline & 15 weeks & 384 abcd & $3.56 \mathrm{abcd}$ & 48.80 ef & $16.58 \mathrm{cdef}$ & $288.57 \mathrm{def}$ \\
\hline & 28 weeks & $3.55 \mathrm{abcd}$ & $3.52 \mathrm{abcd}$ & $42.91 \mathrm{ij}$ & $14.80 \mathrm{efg}$ & $254.99 \mathrm{~h}$ \\
\hline ANOVA & LSD & 2.35 & 1.61 & 4.26 & 2.59 & 28.42 \\
\hline & Oak & 0.5659 & 0.9806 & 0.0013 & 0.138 & 0.0031 \\
\hline & Time & 0.0033 & $<0.0001$ & $<0.0001$ & $<0.0001$ & $<0.0001$ \\
\hline & Interaction & 0.9998 & 0.9972 & 0.0212 & 0.1654 & 0.0435 \\
\hline
\end{tabular}

${ }^{\mathrm{a}} \mathrm{mg} / \mathrm{L}$ unless otherwise noted; ${ }^{\mathrm{b}} \mathrm{mg}$ of corresponding anthocyanin-3-glc equivalents/L; ${ }^{\mathrm{c}}$ sum of phenolic group content; ${ }^{\mathrm{d}} \mathrm{mg} \mathrm{Mv}-3$-glc equivalents/L; ${ }^{\mathrm{e}}$ means with different letters within the same column differ significantly $(\mathrm{P}<0.05) ; \mathrm{CP}(\mathrm{HPLC})=$ coloured polymers measured using HPLC; Dp $=$ delphinidin; glc $=$ glucoside; glc-ac $=$ acetylglucoside; glc-coum = $p$-coumaroylglucoside; $\mathrm{PA}(\mathrm{pH}$ shift $)=$ polymeric anthocyanins measured using the $\mathrm{pH}$ shift assay; $\mathrm{Pt}=\mathrm{petunidin} ; \mathrm{Pn}=\mathrm{peonidin} ; \mathrm{MA}(\mathrm{HPLC})$ $=$ monomeric anthocyanins measured using HPLC; MA ( $\mathrm{pH}$ shift $)=$ monomeric anthocyanins measured using the $\mathrm{pH}$ shift assay; Mv = malvidin; VitA = vitisin A 
A (data not shown), which remained stable during maturation. Maturation using oak products did not affect the vitisin A content (data not shown), whereas none of the treatments affected the content of coloured polymers (data not shown).

Similar trends were observed for the malvidin-3-glucoside (glc), malvidin-3-glucoside-acetate (glc-ac), malvidin-3-glucoside-coumarate (glc-coum) and monomeric anthocyanin content of the wine (Table 1). All the treatments caused a continuous decrease in the content of these compounds throughout the 28-week maturation period. The only exception was the treatment with staves, which caused a significant decrease in the monomeric anthocyanin content of the wine up to 15 weeks' maturation. This decrease was at the same rate as that of the other oak treatments, after which it stabilised. At the completion of maturation, the wines treated with staves had a significantly higher delphinidin-3-glc, petunidin-3glc, malvidin-3-glc, malvidin-3-ac and monomeric anthocyanin content than the wine undergoing the other treatments. The wines matured in stainless steel and new oak barrels had the lowest content of malvidin-3-glc, malvidin-3-glc-ac, malvidin-3-glc-coum and monomeric anthocyanins.

The treatment did not significantly affect the content of the other individual monomeric anthocyanins in the wines (Table 1). Only maturation time affected the content of these compounds. The delphinidin-3-glc and petunidin-3-glc content of the wines matured for 28 weeks (all oak treatments, except staves) and of the wines matured in new barrels for 15 weeks was significantly lower than the content before maturation.

Maturation, irrespective of treatment, resulted in similar trends for the content of unknown flavonols, quercetin-3-rhamnoside (rham), quercetin and total flavonols of the wine, with significantly lower concentrations than in the control wine ( 0 weeks) on completion of maturation (Table 2). The stainless steel and oak extract treatments resulted in a significant decrease in the quercetin-3-glc content of the wines during the maturation period. On completion of maturation, no significant differences were observed between treatments for the flavonol content.

All the wines had a significantly higher content of gallic acid on completion of maturation than the control wine ( 0 weeks) (Table 3 ). After maturation, all the wines matured in oak, except the wine matured in old barrels with staves and oak extract, had a significantly higher gallic acid content than the wine matured in stainless steel. Maturation in stainless steel significantly reduced the caftaric acid, $p$-coumaroyltartaric (coutaric) acid and total phenolic acid content of the wine, while no changes were observed for the caffeic acid content. All oak maturation treatments significantly decreased the caftaric acid and caffeic acid content of the wine to similar final concentrations. The $p$-coumaric acid content of the wines was not significantly different from the control wine ( 0 weeks) after 28 weeks of maturation using stainless steel or oak products (data not shown). All treatments significantly decreased the coutaric acid content of the wine.

TABLE 2

Effect of oak maturation on the flavonol content ${ }^{\mathrm{a}}$ of Pinotage wines.

\begin{tabular}{|c|c|c|c|c|c|c|}
\hline & & Unknown flavonol $^{\mathrm{b}}$ & Quercetin-3-glc & Quercetin-3-rham & Quercetin & Total $^{\mathrm{c}}$ \\
\hline Control & 0 weeks & $14.31 \mathrm{a}^{\mathrm{d}}$ & $10.77 \mathrm{abcd}$ & $8.63 \mathrm{a}$ & 5.17 abcde & $39.78 \mathrm{a}$ \\
\hline \multirow[t]{3}{*}{ Stainless steel } & 6 weeks & $13.25 \mathrm{abc}$ & 10.21 abcdef & $8.32 \mathrm{abc}$ & $6.19 \mathrm{a}$ & $39.13 \mathrm{a}$ \\
\hline & 15 weeks & $12.44 \mathrm{cde}$ & 9.63 abcdef & $8.26 \mathrm{abcd}$ & $5.31 \mathrm{abcd}$ & $36.67 \mathrm{abc}$ \\
\hline & 28 weeks & $10.73 \mathrm{fgh}$ & $7.91 \mathrm{f}$ & $7.09 \mathrm{ij}$ & 3.95 fghi & 30.30 ef \\
\hline \multirow[t]{3}{*}{ New barrels } & 6 weeks & $13.05 \mathrm{bc}$ & $11.38 \mathrm{ab}$ & 8.27 abcd & 4.84 bcdefgh & $38.21 \mathrm{a}$ \\
\hline & 15 weeks & $11.69 \mathrm{def}$ & 9.27 abcdef & 7.66 defghi & 3.93 fghi & $33.14 \mathrm{cdef}$ \\
\hline & 28 weeks & 9.84 ghi & 8.90 cdef & $7.08 \mathrm{ij}$ & $3.73 \mathrm{i}$ & 30.22 ef \\
\hline \multirow[t]{3}{*}{ Second-fill barrels } & 6 weeks & $12.96 \mathrm{bc}$ & $10.80 \mathrm{abcd}$ & $8.36 \mathrm{ab}$ & 5.08 bcde & $38.00 \mathrm{ab}$ \\
\hline & 15 weeks & 11.44 ef & 9.87 abcdef & 7.91 bcdef & 4.45 bcdefghi & $34.35 \mathrm{bcd}$ \\
\hline & 28 weeks & $9.41 \mathrm{i}$ & 8.54 def & $7.17 \mathrm{ij}$ & $3.88 \mathrm{ghi}$ & $29.66 \mathrm{f}$ \\
\hline \multirow[t]{3}{*}{ Third-fill barrels } & 6 weeks & 12.53 bcde & $11.07 \mathrm{abc}$ & $8.23 \mathrm{abcd}$ & $5.31 \mathrm{abcd}$ & $37.95 \mathrm{ab}$ \\
\hline & 15 weeks & $10.78 \mathrm{fgh}$ & 9.36 abcdef & 7.82 bcdefgh & 5.00 bcdef & 33.78 cde \\
\hline & 28 weeks & $9.46 \mathrm{i}$ & 8.50 def & 7.36 fghij & 4.18 bcdefgh & 30.22 ef \\
\hline \multirow[t]{3}{*}{ Chips } & 6 weeks & $13.69 \mathrm{ab}$ & $11.64 \mathrm{a}$ & $8.39 \mathrm{ab}$ & $5.42 \mathrm{abc}$ & $39.97 \mathrm{a}$ \\
\hline & 15 weeks & $10.93 \mathrm{fg}$ & 9.00 bcdef & 7.33 fghij & 4.11 efghi & $32.11 \mathrm{def}$ \\
\hline & 28 weeks & 9.72 hi & 8.59 def & $7.21 \mathrm{hij}$ & 3.97 fghi & 30.27 ef \\
\hline \multirow[t]{3}{*}{ Staves } & 6 weeks & $12.88 \mathrm{bcd}$ & $11.00 \mathrm{abc}$ & 8.10 abcde & $5.28 \mathrm{abcd}$ & $38.04 \mathrm{ab}$ \\
\hline & 15 weeks & $11.19 \mathrm{f}$ & 9.85 abcdef & 7.87 bcdefg & 4.64 bcdefghi & $34.33 \mathrm{bcd}$ \\
\hline & 28 weeks & 9.66 hi & 8.80 cdef & 7.25 ghij & 4.14 efghi & 30.60 def \\
\hline \multirow[t]{3}{*}{ Oak extract } & 6 weeks & $13.30 \mathrm{abc}$ & 10.54 abcde & $8.33 \mathrm{abc}$ & $5.49 \mathrm{ab}$ & $38.48 \mathrm{a}$ \\
\hline & 15 weeks & $11.34 \mathrm{ef}$ & 8.93 cdef & 7.70 cdefghi & 4.66 bcdefghi & 33.54 cde \\
\hline & 28 weeks & $9.49 \mathrm{i}$ & 8.23 ef & $7.22 \mathrm{hij}$ & 4.93 bcdefg & $30.67 \mathrm{def}$ \\
\hline \multirow[t]{3}{*}{ Oak dust } & 6 weeks & $12.87 \mathrm{bcd}$ & 10.52 abcde & $8.11 \mathrm{abcd}$ & 4.37 cdefghi & $36.54 \mathrm{abc}$ \\
\hline & 15 weeks & $10.99 \mathrm{fg}$ & $10.25 \mathrm{abcdef}$ & 7.48 efghi & 4.24 defghi & $33.66 \mathrm{bcd}$ \\
\hline & 28 weeks & $9.17 \mathrm{i}$ & 10.17 abcdef & $6.75 \mathrm{j}$ & $3.81 \mathrm{hi}$ & 30.52 def \\
\hline \multirow[t]{4}{*}{ ANOVA } & LSD & 1.21 & 2.42 & 0.64 & 1.10 & 3.84 \\
\hline & Oak & $<0.0001$ & 0.8915 & 0.0283 & 0.0053 & 0.0423 \\
\hline & Time & $<0.0001$ & 0.0002 & $<0.0001$ & $<0.0001$ & $<0.0001$ \\
\hline & Interaction & 0.9502 & 0.9686 & 0.8828 & 0.9192 & 0.9154 \\
\hline
\end{tabular}

${ }^{\mathrm{a}} \mathrm{mg} / \mathrm{L}$ unless otherwise noted; ${ }^{\mathrm{b}} \mathrm{mg}$ rutin equivalents $/ \mathrm{L} ;{ }^{\mathrm{c}}$ sum of phenolic group content; ${ }^{\mathrm{d}}$ means with different letters within the same column differ significantly $(\mathrm{P}<0.05$ ). 
TABLE 3

Effect of oak maturation on the phenolic acid content ${ }^{\mathrm{a}}$ of Pinotage wines.

\begin{tabular}{|c|c|c|c|c|c|c|}
\hline & & Gallic acid & Caftaric acid & Caffeic acid & Coutaric acid ${ }^{b}$ & Total $^{\mathrm{c}}$ \\
\hline Control & 0 weeks & $23.99 \mathrm{kl}^{\mathrm{d}}$ & 88.48 a & $21.25 \mathrm{abc}$ & $6.90 \mathrm{ab}$ & $144.03 \mathrm{abc}$ \\
\hline \multirow[t]{3}{*}{ Stainless steel } & 6 weeks & $23.96 \mathrm{kl}$ & 85.62 abcd & $21.93 \mathrm{a}$ & $7.31 \mathrm{a}$ & $142.78 \mathrm{abc}$ \\
\hline & 15 weeks & $24.53 \mathrm{ijkl}$ & 81.61 bcde & $21.35 \mathrm{ab}$ & $6.93 \mathrm{ab}$ & $138.45 \mathrm{abcd}$ \\
\hline & 28 weeks & $25.99 \mathrm{efgh}$ & $71.81 \mathrm{f}$ & 20.52 abcdef & $3.45 \mathrm{~cd}$ & $131.65 \mathrm{~d}$ \\
\hline \multirow[t]{3}{*}{ New barrels } & 6 weeks & 25.05 ghij & 83.94 abcde & 20.26 abcdef & $6.58 \mathrm{~b}$ & $139.23 \mathrm{abcd}$ \\
\hline & 15 weeks & $26.36 \mathrm{cdef}$ & 84.86 abcd & $19.73 \mathrm{cdefgh}$ & $3.33 \mathrm{~cd}$ & $141.05 \mathrm{a}$ \\
\hline & 28 weeks & $27.72 \mathrm{a}$ & $79.03 \mathrm{de}$ & $18.33 \mathrm{~h}$ & $3.78 \mathrm{~cd}$ & $134.03 \mathrm{abc}$ \\
\hline \multirow[t]{3}{*}{ Second-fill barrels } & 6 weeks & $24.63 \mathrm{ijkl}$ & 83.14 abcde & 20.63 abcde & $6.86 \mathrm{ab}$ & $138.80 \mathrm{abcd}$ \\
\hline & 15 weeks & $26.03 \mathrm{defg}$ & 83.76 abcde & 19.36 defgh & $3.29 \mathrm{~d}$ & $139.18 \mathrm{abc}$ \\
\hline & 28 weeks & $27.60 \mathrm{ab}$ & 77.21 ef & $18.46 \mathrm{~h}$ & $3.71 \mathrm{~cd}$ & $132.30 \mathrm{bcd}$ \\
\hline \multirow[t]{3}{*}{ Third-fill barrels } & 6 weeks & $24.33 \mathrm{jkl}$ & 85.14 abcd & 20.43 abcdef & $6.61 \mathrm{ab}$ & $140.13 \mathrm{abc}$ \\
\hline & 15 weeks & $25.00 \mathrm{hij}$ & 83.48 abcde & 19.24 defgh & $3.42 \mathrm{~cd}$ & $138.19 \mathrm{abc}$ \\
\hline & 28 weeks & $27.00 \mathrm{abcd}$ & $79.79 \mathrm{de}$ & $18.66 \mathrm{gh}$ & $3.63 \mathrm{~cd}$ & $135.01 \mathrm{abcd}$ \\
\hline \multirow[t]{3}{*}{ Chips } & 6 weeks & $24.79 \mathrm{ijkl}$ & $86.90 \mathrm{ab}$ & 20.07 bcdefg & $6.64 \mathrm{ab}$ & $141.75 \mathrm{abc}$ \\
\hline & 15 weeks & 25.48 fghi & 83.17 abcde & $19.16 \mathrm{efgh}$ & $3.21 \mathrm{~d}$ & $138.21 \mathrm{abc}$ \\
\hline & 28 weeks & $27.30 \mathrm{abc}$ & 80.81 bcde & $18.51 \mathrm{~h}$ & $3.66 \mathrm{~cd}$ & $136.35 \mathrm{abc}$ \\
\hline \multirow[t]{3}{*}{ Staves } & 6 weeks & 23.901 & 82.68 abcde & 20.67 abcde & $6.69 \mathrm{ab}$ & $137.22 \mathrm{~cd}$ \\
\hline & 15 weeks & 24.94 ijk & 82.63 abcde & 19.38 defgh & $4.03 \mathrm{c}$ & $137.00 \mathrm{abc}$ \\
\hline & 28 weeks & $26.57 \mathrm{cde}$ & $79.43 \mathrm{de}$ & $18.46 \mathrm{~h}$ & $3.63 \mathrm{~cd}$ & $133.78 \mathrm{bcd}$ \\
\hline \multirow[t]{3}{*}{ Oak extract } & 6 weeks & $24.24 \mathrm{jkl}$ & $86.61 \mathrm{abc}$ & 20.40 abcdef & $6.77 \mathrm{ab}$ & $141.44 \mathrm{abc}$ \\
\hline & 15 weeks & $24.83 \mathrm{ijkl}$ & 83.64 abcde & 19.56 defgh & $3.55 \mathrm{~cd}$ & $138.26 \mathrm{abc}$ \\
\hline & 28 weeks & 26.71 bcde & 80.03 cde & $18.45 \mathrm{~h}$ & $3.31 \mathrm{~cd}$ & $134.29 \mathrm{bcd}$ \\
\hline \multirow[t]{3}{*}{ Oak dust } & 6 weeks & $24.72 \mathrm{ijkl}$ & $85.46 \mathrm{abcd}$ & $20.74 \mathrm{abcd}$ & $7.01 \mathrm{ab}$ & $141.15 \mathrm{abc}$ \\
\hline & 15 weeks & 25.49 fghi & $85.68 \mathrm{abcd}$ & 19.77 cdefgh & $3.85 \mathrm{~cd}$ & $141.29 \mathrm{ab}$ \\
\hline & 28 weeks & $27.03 \mathrm{abc}$ & 79.98 cde & $19.02 \mathrm{fgh}$ & $3.84 \mathrm{~cd}$ & $135.58 \mathrm{abc}$ \\
\hline \multirow[t]{4}{*}{ ANOVA } & LSD & 1.00 & 6.82 & 1.55 & 0.73 & 7.84 \\
\hline & Oak & $<0.0001$ & 0.7499 & $<0.0001$ & $<0.0001$ & 0.8172 \\
\hline & Time & $<0.0001$ & $<0.0001$ & $<0.0001$ & $<0.0001$ & 0.0029 \\
\hline & Interaction & 0.9911 & 0.9961 & 0.9999 & 0.7625 & 0.9977 \\
\hline
\end{tabular}

${ }^{\mathrm{a}} \mathrm{mg} / \mathrm{L}$ unless other wise noted; ${ }^{\mathrm{b}} \mathrm{mg} p$-coumaric acid equivalents $/ \mathrm{L} ;{ }^{\mathrm{c}}$ sum of phenolic group content; ${ }^{\mathrm{d}}$ means with different letters within the same column differ significantly $(\mathrm{P}<0.05)$.

Maturation using new barrels, second-fill barrels and oak dust significantly decreased the $(+)$-catechin content, while only the wine from the new-barrel treatment had a significantly lower procyanidin B1 content after the completion of maturation (Table 4). No significant change in the content of non-coloured polymers was observed for the individual treatments after maturation, except in the wine treated in new barrels, which had a much lower content on completion of maturation compared to the control wine ( 0 weeks). No changes in flavan-3-ol content were observed after maturation in stainless steel containers.

After the completion of maturation, only the wines matured using new barrels and chips had a significantly lower total phenol content than the control wine (0 weeks) (Table 4$)$. The total monomer content was decreased for all the treatments, with the most substantial decrease being for the stainless steel and newbarrel treatments, followed by the second- and third-fill barrel treatments. The smallest decrease in total monomer content was observed for treatments using old barrels with alternative oak sources.

\section{Antioxidant capacity}

The trends for the $\mathrm{TAC}_{\mathrm{M}}$ of the individual treatments differed (Table 5). The wines treated in new barrels and with oak extract had significantly higher $\mathrm{TAC}_{\mathrm{M}}$ values than the control wine ( 0 weeks) after six weeks' maturation, but thereafter their $\mathrm{TAC}_{\mathrm{M}}$ values decreased. Subsequently, the $\mathrm{TAC}_{\mathrm{M}}$ values of new barreland oak extract-treated wine were not significantly different from the control wine after 15 and 28 weeks' maturation. The wine treated with oak dust showed a significantly higher $\mathrm{TAC}_{\mathrm{M}}$ than the control wine ( 0 weeks) after 15 weeks' maturation. However, the $\mathrm{TAC}_{\mathrm{M}}$ of none of the oak-treated wines or the wine matured in stainless steel was significantly different from that of the control wine ( 0 weeks) on completion of maturation. All the wines had a significantly lower $\mathrm{TAC}_{\mathrm{CAL}}$ than the control wine (0 weeks) on completion of maturation. The wines treated in new barrels and stainless steel had the lowest $\mathrm{TAC}_{\mathrm{CAL}}$, while the wine treated with staves had the highest $\mathrm{TAC}_{\mathrm{CAL}}$. The $\mathrm{TAC}_{\mathrm{R}}$ followed a similar trend to the $\mathrm{TAC}_{\mathrm{M}}$.

\section{Objective colour parameters}

The trends for the $C^{*}$ and $a^{*}$ values of the wine over the maturation period were very similar (Table 6 ). Oak maturation caused a significant increase in the $C^{*}$ and $a^{*}$ values of the wine from zero weeks to six weeks, after which a decrease was observed. The $C^{*}$ and $\mathrm{a}^{*}$ of wine matured in stainless steel showed the opposite trend. However, after maturation only the wines matured using new barrels, second-fill barrels, third-fill barrels and oak extract had C* values significantly lower than that of the control wine (0 weeks). The $a^{*}$ values of all the wines after completion of maturation were significantly lower than that of the control wine ( 0 weeks). 
TABLE 4

Effect of oak maturation on the flavan-3-ol, total monomer and total phenol content ${ }^{\mathrm{a}}$ of Pinotage wines.

\begin{tabular}{|c|c|c|c|c|c|c|}
\hline & & $(+)$-Catechin & Procyanidin B1 & $\begin{array}{c}\text { Non-coloured } \\
\text { polymers }^{b}\end{array}$ & Total monomers ${ }^{\mathrm{c}}$ & $\begin{array}{l}\text { TP (Folin- } \\
\text { Ciocalteau) }^{\mathrm{d}}\end{array}$ \\
\hline Control & 0 weeks & $33.73 \mathrm{bcd}^{\mathrm{e}}$ & $19.27 \mathrm{a}$ & $67.70 \mathrm{a}$ & $567.42 \mathrm{a}$ & 1984.4 abcdef \\
\hline \multirow[t]{3}{*}{ Stainless steel } & 6 weeks & 32.85 bcde & $17.48 \mathrm{abcd}$ & $61.13 \mathrm{a}$ & $550.97 \mathrm{abc}$ & 1945.8 bcdefg \\
\hline & 15 weeks & $38.83 \mathrm{a}$ & $18.13 \mathrm{abcd}$ & $75.94 \mathrm{a}$ & 526.92 bcdef & $1904.4 \mathrm{efg}$ \\
\hline & 28 weeks & $31.59 \mathrm{cde}$ & $17.42 \mathrm{abcd}$ & $70.22 \mathrm{a}$ & 402.191 & $1888.0 \mathrm{fg}$ \\
\hline \multirow[t]{3}{*}{ New barrels } & 6 weeks & $30.72 \mathrm{cdef}$ & $16.87 \mathrm{abcd}$ & $67.81 \mathrm{a}$ & 536.46 abcdef & $2049.0 \mathrm{abc}$ \\
\hline & 15 weeks & 28.76 ef & $15.32 \mathrm{~d}$ & $67.81 \mathrm{a}$ & 483.36 ghij & 1949.0 bcdefg \\
\hline & 28 weeks & $26.99 \mathrm{f}$ & $15.93 \mathrm{~cd}$ & $38.44 \mathrm{~b}$ & 413.841 & $1857.5 \mathrm{~g}$ \\
\hline \multirow[t]{3}{*}{ Second-fill barrels } & 6 weeks & 32.70 bcde & $18.13 \mathrm{abcd}$ & $59.24 \mathrm{a}$ & 542.98 abcde & 1962.1 bcdefg \\
\hline & 15 weeks & $30.43 \mathrm{cdef}$ & $16.25 \mathrm{bcd}$ & $70.71 \mathrm{a}$ & 505.20 fghi & 1948.8 bcdefg \\
\hline & 28 weeks & $28.92 \mathrm{ef}$ & $17.31 \mathrm{abcd}$ & $60.64 \mathrm{a}$ & $449.36 \mathrm{k}$ & $1922.7 \mathrm{defg}$ \\
\hline \multirow[t]{3}{*}{ Third-fill barrels } & 6 weeks & 32.07 bcde & $19.21 \mathrm{ab}$ & $61.59 \mathrm{a}$ & $551.33 \mathrm{abc}$ & 2027.4 abcd \\
\hline & 15 weeks & $29.86 \mathrm{cdef}$ & $16.42 \mathrm{abcd}$ & $70.47 \mathrm{a}$ & $516.13 \mathrm{cdefg}$ & 1962.9 bcdefg \\
\hline & 28 weeks & 30.79 cdef & $18.28 \mathrm{abc}$ & $66.57 \mathrm{a}$ & $471.53 \mathrm{jk}$ & 1941.2 cdefg \\
\hline \multirow[t]{3}{*}{ Chips } & 6 weeks & 31.65 cde & $18.84 \mathrm{abc}$ & $74.18 \mathrm{a}$ & $553.54 \mathrm{abc}$ & $2056.4 \mathrm{ab}$ \\
\hline & 15 weeks & $29.30 \mathrm{def}$ & $18.46 \mathrm{abc}$ & $65.01 \mathrm{a}$ & 506.63 efghi & 1942.6 bcdefg \\
\hline & 28 weeks & 33.15 bcde & $17.31 \mathrm{abcd}$ & $66.21 \mathrm{a}$ & $475.71 \mathrm{ijk}$ & $1850.9 \mathrm{~g}$ \\
\hline \multirow[t]{3}{*}{ Staves } & 6 weeks & 32.41 bcde & $17.47 \mathrm{abcd}$ & $60.05 \mathrm{a}$ & 538.55 abcdef & 1990.9 abcdef \\
\hline & 15 weeks & $33.95 \mathrm{bc}$ & $16.79 \mathrm{abcd}$ & $65.52 \mathrm{a}$ & 512.35 defgh & $1911.0 \mathrm{efg}$ \\
\hline & 28 weeks & $30.44 \mathrm{cdef}$ & $17.46 \mathrm{abcd}$ & $64.68 \mathrm{a}$ & 507.89 efgh & $1909.0 \mathrm{efg}$ \\
\hline \multirow[t]{3}{*}{ Oak extract } & 6 weeks & 32.41 bcde & $17.58 \mathrm{abcd}$ & $69.49 \mathrm{a}$ & $554.31 \mathrm{ab}$ & $2096.4 \mathrm{a}$ \\
\hline & 15 weeks & $36.24 \mathrm{ab}$ & $18.31 \mathrm{abc}$ & $67.80 \mathrm{a}$ & 524.24 bcdef & 1956.2 bcdefg \\
\hline & 28 weeks & $31.31 \mathrm{cdef}$ & $18.31 \mathrm{abc}$ & $63.74 \mathrm{a}$ & $458.24 \mathrm{jk}$ & 1921.0 defg \\
\hline \multirow[t]{3}{*}{ Oak dust } & 6 weeks & $30.95 \mathrm{cdef}$ & $16.97 \mathrm{abcd}$ & $64.12 \mathrm{a}$ & 545.62 abcd & 2007.4 abcde \\
\hline & 15 weeks & 32.74 bcde & $17.13 \mathrm{abcd}$ & $65.07 \mathrm{a}$ & 513.39 defgh & 2005.2 abcde \\
\hline & 28 weeks & $28.88 \mathrm{ef}$ & $16.34 \mathrm{bcd}$ & $66.44 \mathrm{a}$ & 481.01 hijk & 1950.0 bcdefg \\
\hline \multirow[t]{4}{*}{ ANOVA } & LSD & 4.45 & 2.92 & 17.65 & 32.70 & 114.4 \\
\hline & Oak & 0.0018 & 0.1329 & 0.5172 & 0.0017 & 0.3044 \\
\hline & Time & 0.0054 & 0.4616 & 0.2879 & $<0.0001$ & $<0.0001$ \\
\hline & Interaction & 0.2539 & 0.9038 & 0.3074 & 0.0815 & 0.5406 \\
\hline
\end{tabular}

${ }^{\mathrm{a}} \mathrm{mg} / \mathrm{L}$ unless other wise noted; ${ }^{\mathrm{b}} \mathrm{mg}(+)$-catechin equivalents/L; ${ }^{\mathrm{c}}$ sum of all monomeric phenolic compounds; ${ }^{\mathrm{d}}$ mg gallic acid equivalents/L; ${ }^{\mathrm{e}}$ means with different letters within the same column differ significantly $(\mathrm{P}<0.05)$;F $(\mathrm{DAC})=$ total flavan-3-ols measured using the DAC assay; TP $($ Folin-Ciocalteau $)=$ total phenols measured using the Folin-Ciocalteau assay.

Oak maturation initially caused a decrease in wine $h^{*}$ only for the wines treated with oak extract and oak dust, after which an increase was observed. These wines showed an increase throughout the maturation period. A similar trends were seen for the $b^{*}$ values, except that only the stainless steel treatment showed an initial decrease. All the matured wines had significantly higher $h^{*}$ and $b^{*}$ values than that of the control wine ( 0 weeks) after completion of maturation. The least change in $h^{*}$ and $b^{*}$ values was observed for the wine treated in new barrels, which had significantly lower values than the other oak and stainless steel treatments. Progressively lower $h^{*}$ values were observed for wines matured in thirdfill barrels, second-fill barrels and new barrels with alternative oak products, giving values between that of second- and third-fill barrels on completion of maturation.

The $L^{*}$ values of the wine decreased significantly during oak maturation and were significantly lower than that of the control wine ( 0 weeks). The trends for the $L^{*}$ values of the individual treatments were similar, with the wines treated in new barrels showing a much more pronounced decrease than the other wines, resulting in wine with the lowest $L^{*}$ value.

\section{Canonical discriminant analysis}

Forward step-wise variable selection resulted in the selection of malvidin-3-glc, delphinidin-3-glc, petunidin-3-glc, peonidin-3-glc- ac, quercetin-3-rham, gallic acid, caffeic acid, total phenolic acids and $\mathrm{a}^{*}$ value as the most discriminating factors. A plot of the variable loadings is given in Fig. 1. A canonical discriminant analysis plot of the data shows that the control wines are mostly separated from the rest of the wines, with wines treated in new barrels and with staves also separated from the rest of the wines (Fig. 2). All other alternative oak treatments, as well as second- and third-fill barrel treatments, were grouped together.

\section{DISCUSSION}

Monomeric anthocyanins are increasingly incorporated into oligomeric and polymeric pigments during maturation, a process that, for many high-quality red wines, starts with oak maturation. Direct and acetaldehyde-mediated condensation of anthocyanins and flavan-3-ols gives rise to oligomeric and eventually polymeric pigments with greater colour stability than the original pigments (Fulcrand et al., 2004). In the present study, the total monomeric anthocyanin content and total flavan-3-ol content of Pinotage wine decreased with oak maturation in new barrels, but the coloured polymer content unexpectedly did not increase. A possible explanation is that only coloured oligomers were formed during the short maturation period of 28 weeks, and that these are not detected in the coloured polymer HPLC peak (only five or more subunits) (Peng et al., 2002). The monomeric anthocyanin content 
TABLE 5

Effect of oak maturation on the antioxidant capacity and objective colour parameters of Pinotage wines.

\begin{tabular}{|c|c|c|c|c|}
\hline & & TAC $_{M}{ }^{a}$ & TAC $_{\text {CAL }}{ }^{b}$ & TAC $_{R}{ }^{c}$ \\
\hline Control & 0 weeks & $14.33 \mathrm{de}^{\mathrm{i}}$ & $2.01 \mathrm{a}$ & $12.31 \mathrm{de}$ \\
\hline \multirow[t]{3}{*}{ Stainless steel } & 6 weeks & 14.61 bcde & $1.96 \mathrm{abcd}$ & 12.65 bcde \\
\hline & 15 weeks & 14.49 bcde & 1.91 abcdef & 12.58 bcde \\
\hline & 28 weeks & 14.59 bcde & $1.54 \mathrm{j}$ & 13.01 abcde \\
\hline \multirow[t]{3}{*}{ New barrels } & 6 weeks & $15.34 \mathrm{abc}$ & 1.93 abcde & $13.41 \mathrm{abc}$ \\
\hline & 15 weeks & 14.38 cde & $1.79 \mathrm{hi}$ & 12.59 bcde \\
\hline & 28 weeks & $14.36 \mathrm{de}$ & $1.61 \mathrm{j}$ & 12.75 bcde \\
\hline \multirow[t]{3}{*}{ Second-fill barrels } & 6 weeks & $14.34 \mathrm{de}$ & 1.95 abcde & $12.40 \mathrm{cde}$ \\
\hline & 15 weeks & 14.58 bcde & $1.85 \mathrm{efgh}$ & 12.73 bcde \\
\hline & 28 weeks & 14.77 bcde & $1.72 \mathrm{i}$ & 13.06 abcde \\
\hline \multirow[t]{3}{*}{ Third-fill barrels } & 6 weeks & $15.02 \mathrm{abcd}$ & $1.97 \mathrm{abc}$ & 13.04 abcde \\
\hline & 15 weeks & 14.99 abcde & 1.88 cdefgh & 13.11 abcde \\
\hline & 28 weeks & 14.95 abcde & $1.77 \mathrm{hi}$ & 13.17 abcde \\
\hline \multirow[t]{3}{*}{ Chips } & 6 weeks & $15.29 \mathrm{abcd}$ & $1.98 \mathrm{ab}$ & $13.30 \mathrm{abcd}$ \\
\hline & 15 weeks & 14.79 abcde & $1.85 \mathrm{efgh}$ & 12.94 abcde \\
\hline & 28 weeks & $14.02 \mathrm{e}$ & $1.79 \mathrm{ghi}$ & $12.22 \mathrm{e}$ \\
\hline \multirow[t]{3}{*}{ Staves } & 6 weeks & 14.91 abcde & 1.93 abcde & 12.98 abcde \\
\hline & 15 weeks & 14.65 bcde & 1.86 defgh & 12.79 bcde \\
\hline & 28 weeks & 14.65 bcde & 1.87 cdefgh & 12.77 abcde \\
\hline \multirow[t]{3}{*}{ Oak extract } & 6 weeks & $15.76 \mathrm{a}$ & $1.98 \mathrm{abc}$ & $13.79 \mathrm{a}$ \\
\hline & 15 weeks & 14.98 abcde & 1.90 bcdefg & 13.07 abcde \\
\hline & 28 weeks & 14.58 bcde & $1.73 \mathrm{i}$ & 12.85 abcde \\
\hline \multirow[t]{3}{*}{ Oak dust } & 6 weeks & $15.13 \mathrm{abcd}$ & 1.96 abcde & 13.17 abcde \\
\hline & 15 weeks & $15.42 \mathrm{ab}$ & $1.87 \mathrm{cdefgh}$ & $13.55 \mathrm{ab}$ \\
\hline & 28 weeks & 14.99 abcde & $1.80 \mathrm{fghi}$ & $13.45 \mathrm{ab}$ \\
\hline \multirow[t]{4}{*}{ ANOVA } & LSD & 0.98 & 0.11 & 1.01 \\
\hline & Oak & 0.1081 & 0.0128 & 0.0985 \\
\hline & Time & 0.2065 & $<0.0001$ & 0.6419 \\
\hline & Interaction & 0.3732 & 0.1683 & 0.4278 \\
\hline
\end{tabular}

a total antioxidant capacity in $\mathrm{mM}$ Trolox equivalents; ${ }^{\mathrm{b}}$ total antioxidant capacity in $\mathrm{mM}$ Trolox equivalents as calculated from the content of monomeric phenolic compounds and their Trolox equivalent antioxidant capacity; ${ }^{\mathrm{c}}$ unexplained TAC $=$ measured TAC - calculated TAC; ${ }^{\mathrm{i}}$ means with different letters within the same column differ significantly $(\mathrm{P}<0.05)$.

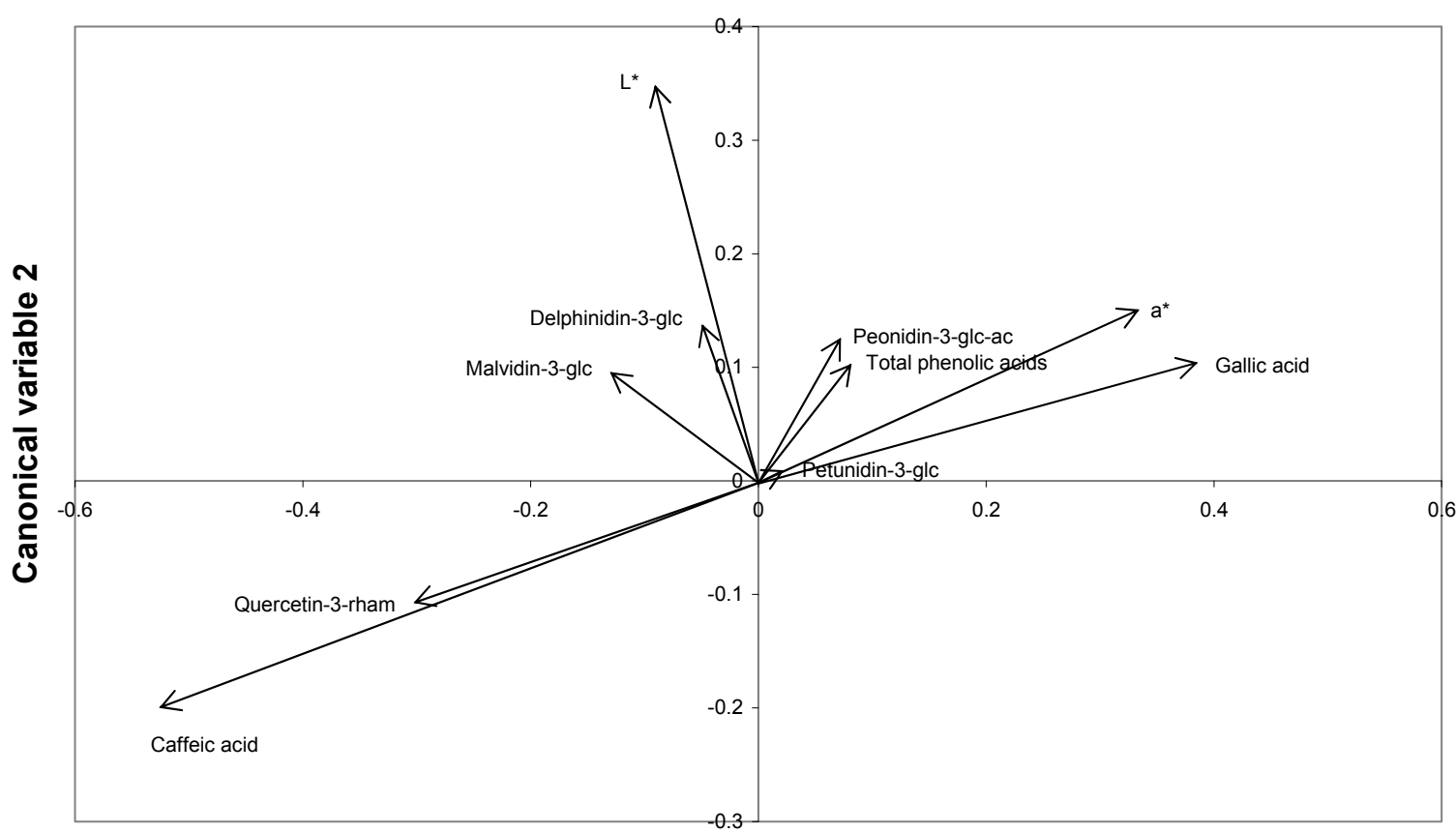

Canonical variable 1

FIGURE 1

Canonical discriminant analysis plot of variable loadings. 


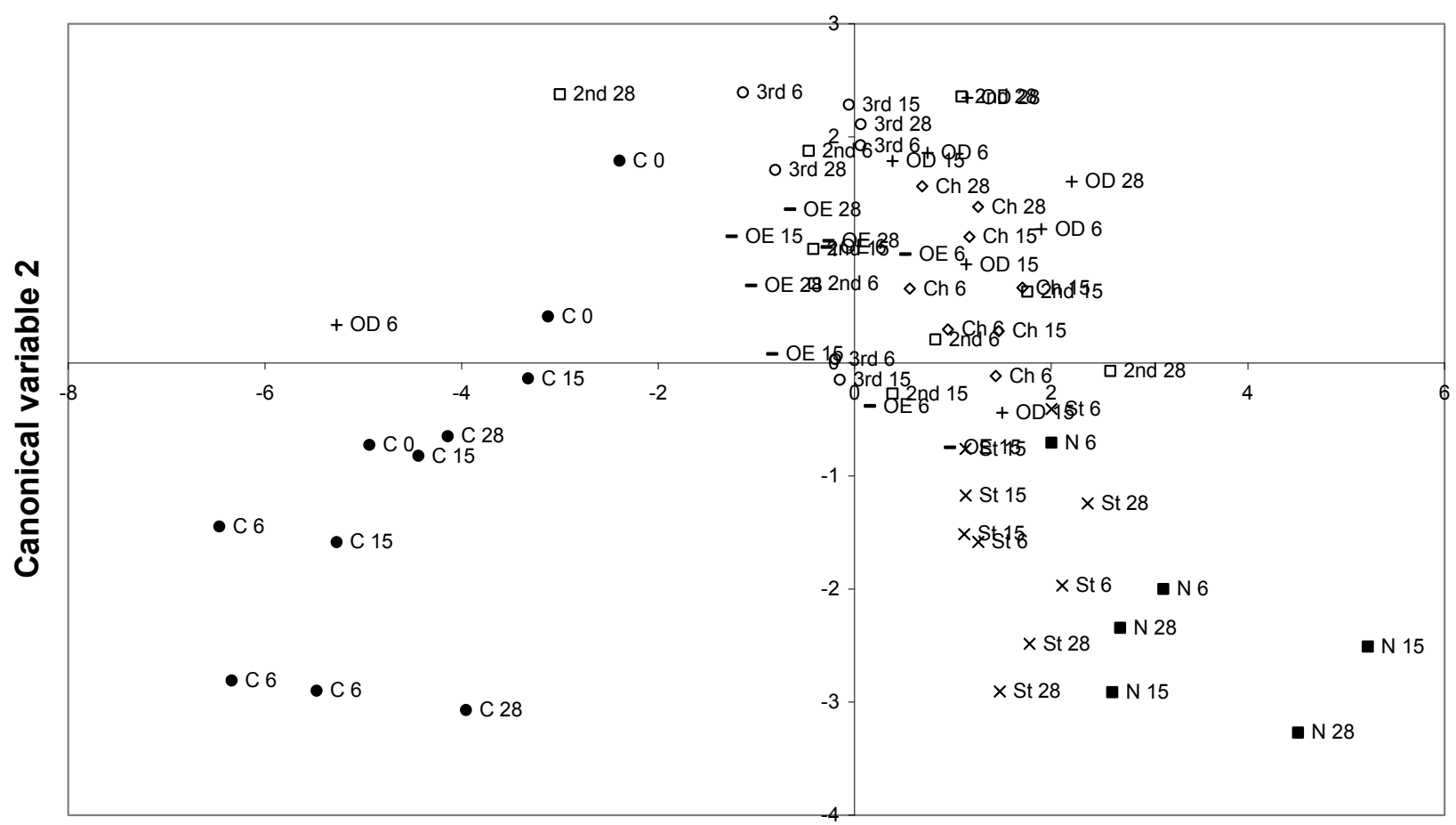

\section{Canonical variable 1}

FIGURE 2

Canonical discriminant analysis plot of wines ( $\bullet$ control; - new barrels; $\square$ second fill barrels; $\circ$ third fill barrels; $\diamond$ chips; $\mathrm{x}$ staves; - oak extract; + oak dust).

TABLE 6

Effect of oak maturation on the objective colour parameters of Pinotage wines.

\begin{tabular}{|c|c|c|c|c|c|c|}
\hline & & $C^{* \mathrm{~d}}$ & $h^{* \mathrm{e}}$ & $L^{* \mathrm{f}}$ & $a^{* g}$ & $b^{\text {*h }}$ \\
\hline Control & 0 weeks & $61.90 \mathrm{defg}$ & $17.67 \mathrm{ijk}$ & $31.52 \mathrm{abc}$ & $58.98 \mathrm{~cd}$ & $18.79 \mathrm{ij}$ \\
\hline \multirow[t]{3}{*}{ Stainless steel } & 6 weeks & $58.56 \mathrm{j}$ & $17.96 \mathrm{ghi}$ & 29.58 ghij & $55.71 \mathrm{~h}$ & $18.06 \mathrm{k}$ \\
\hline & 15 weeks & $62.13 \mathrm{cde}$ & $18.79 \mathrm{e}$ & 30.19 efgh & $58.82 \mathrm{~d}$ & $20.01 \mathrm{cde}$ \\
\hline & 28 weeks & $62.22 \mathrm{~cd}$ & $20.64 \mathrm{abc}$ & $28.00 \mathrm{k}$ & $58.22 \mathrm{e}$ & $21.94 \mathrm{a}$ \\
\hline \multirow[t]{3}{*}{ New barrels } & 6 weeks & $64.36 \mathrm{a}$ & $17.86 \mathrm{hij}$ & $30.64 \mathrm{cdef}$ & $61.26 \mathrm{ab}$ & $19.74 \mathrm{def}$ \\
\hline & 15 weeks & $62.49 \mathrm{c}$ & $18.16 \mathrm{ghi}$ & $28.19 \mathrm{k}$ & $59.38 \mathrm{c}$ & 19.48 efgh \\
\hline & 28 weeks & $61.12 \mathrm{i}$ & $19.53 \mathrm{~d}$ & 26.231 & $57.61 \mathrm{fg}$ & $20.44 \mathrm{efgh}$ \\
\hline \multirow[t]{3}{*}{ Second-fill barrels } & 6 weeks & $63.99 \mathrm{ab}$ & $17.30 \mathrm{kl}$ & $31.69 \mathrm{ab}$ & $61.10 \mathrm{~b}$ & $19.03 \mathrm{hi}$ \\
\hline & 15 weeks & $62.24 \mathrm{~cd}$ & $18.51 \mathrm{ef}$ & $29.81 \mathrm{fghi}$ & $59.02 \mathrm{~cd}$ & $19.77 \mathrm{def}$ \\
\hline & 28 weeks & $61.38 \mathrm{hi}$ & $20.30 \mathrm{c}$ & $28.21 \mathrm{k}$ & $57.58 \mathrm{fg}$ & $21.29 \mathrm{~b}$ \\
\hline \multirow[t]{3}{*}{ Third-fill barrels } & 6 weeks & $63.80 \mathrm{~b}$ & $17.16 \mathrm{klm}$ & $31.99 \mathrm{a}$ & $60.96 \mathrm{~b}$ & $18.82 \mathrm{ij}$ \\
\hline & 15 weeks & $62.13 \mathrm{cde}$ & $18.84 \mathrm{e}$ & 30.88 bcde & $58.81 \mathrm{~d}$ & $20.06 \mathrm{~cd}$ \\
\hline & 28 weeks & $61.36 \mathrm{hi}$ & $21.00 \mathrm{a}$ & 29.34 hij & $57.29 \mathrm{~g}$ & $21.99 \mathrm{a}$ \\
\hline \multirow[t]{3}{*}{ Chips } & 6 weeks & $64.03 \mathrm{ab}$ & $17.41 \mathrm{jkl}$ & $31.42 \mathrm{abcd}$ & $61.10 \mathrm{~b}$ & $19.16 \mathrm{ghi}$ \\
\hline & 15 weeks & $61.95 \mathrm{defg}$ & $18.53 \mathrm{ef}$ & $30.18 \mathrm{efgh}$ & $58.74 \mathrm{~d}$ & $19.69 \mathrm{defg}$ \\
\hline & 28 weeks & 61.57 fghi & $20.59 \mathrm{abc}$ & $28.73 \mathrm{jk}$ & $57.64 \mathrm{fg}$ & $21.65 \mathrm{ab}$ \\
\hline \multirow[t]{3}{*}{ Staves } & 6 weeks & $64.17 \mathrm{ab}$ & $16.92 \mathrm{klm}$ & $31.65 \mathrm{ab}$ & $61.39 \mathrm{ab}$ & $18.68 \mathrm{ij}$ \\
\hline & 15 weeks & $62.01 \mathrm{def}$ & $18.58 \mathrm{~lm}$ & $30.34 \mathrm{efg}$ & $58.78 \mathrm{~d}$ & $19.76 \mathrm{def}$ \\
\hline & 28 weeks & $61.68 \mathrm{efgh}$ & $20.52 a b c$ & $28.89 \mathrm{ijk}$ & 57.77 ef & $21.62 \mathrm{ab}$ \\
\hline \multirow[t]{3}{*}{ Oak extract } & 6 weeks & $64.14 \mathrm{ab}$ & $16.87 \mathrm{~lm}$ & $31.79 \mathrm{ab}$ & $61.39 \mathrm{ab}$ & $18.62 \mathrm{ijk}$ \\
\hline & 15 weeks & $61.95 \mathrm{defg}$ & $18.43 \mathrm{efg}$ & $30.78 \mathrm{defg}$ & $58.78 \mathrm{~d}$ & $19.58 \mathrm{defgh}$ \\
\hline & 28 weeks & $61.25 \mathrm{hi}$ & $20.84 \mathrm{ab}$ & $28.85 \mathrm{ijk}$ & $57.25 \mathrm{~g}$ & $21.79 \mathrm{ab}$ \\
\hline \multirow[t]{3}{*}{ Oak dust } & 6 weeks & $64.28 \mathrm{a}$ & $16.65 \mathrm{~m}$ & $31.59 \mathrm{abc}$ & $61.59 \mathrm{a}$ & $18.42 \mathrm{jk}$ \\
\hline & 15 weeks & $62.03 \mathrm{cde}$ & $18.24 \mathrm{fgh}$ & $30.21 \mathrm{efgh}$ & $58.91 \mathrm{~cd}$ & $19.42 \mathrm{fgh}$ \\
\hline & 28 weeks & $61.52 \mathrm{ghi}$ & $20.39 \mathrm{bc}$ & $28.73 \mathrm{jk}$ & $57.67 \mathrm{fg}$ & $21.44 \mathrm{ab}$ \\
\hline \multirow[t]{4}{*}{ ANOVA } & LSD & 0.46 & 0.54 & 0.96 & 0.48 & 0.57 \\
\hline & Oak & $<0.0001$ & 0.1478 & $<0.0001$ & $<0.0001$ & 0.0378 \\
\hline & Time & $<0.0001$ & $<0.0001$ & $<0.0001$ & $<0.0001$ & $<0.0001$ \\
\hline & Interaction & 0.1521 & 0.005 & 0.6540 & 0.2678 & 0.0002 \\
\hline
\end{tabular}

${ }_{\mathrm{d}}^{\mathrm{d}}$ chroma; ${ }^{\mathrm{e}}$ hue angle $\left({ }^{\circ}\right) ;{ }^{\mathrm{f}}$ lightness; ${ }^{\mathrm{g}}$ red/green chromaticity; ${ }^{\mathrm{h}}$ yellow/blue chromaticity; ${ }^{\mathrm{i}}$ means with different letters within the same column differ significantly $(\mathrm{P}<0.05)$. 
also decreased during oak maturation using alternative oak products, as well as when no oak products were used during maturation. Some oak treatments, namely third-fill barrels, chips, staves and oak extract, however, did not cause a decrease in flavan-3-ol content. In these cases, oxidative degradation of the monomeric anthocyanins might have taken place. The decrease in flavonol (unknown flavonol and quercetin-3-rham) and hydroxycinnamic acid (caftaric, caffeic and coutaric acid) content of the wine is also attributed to oxidative degradation as a result of maturation. Similar results were obtained by Hernández et al. (2006). Products of oxidative degradation of $o$-diphenols include $o$-quinones, which can react further to form brown polymers (Cheynier et al., 1988), or adducts with glutathione and sulphur dioxide (Singleton et al., 1985; Rigaud et al., 1991).

The decrease in the content of individual anthocyanins was more pronounced for new barrels than for the other treatments. The greater decrease in monomeric anthocyanin and flavan-3-ol content observed for wines matured in new barrels is presumably due to a higher rate of acetaldehyde-mediated condensation reactions. A higher content of dissolved oxygen has been reported for wine in new barrels than in used barrels (Castellari et al., 2004), which could increase the acetaldehyde content of the wine. New barrels also contain higher levels of hydrolysable tannins, which have a higher oxidising capacity than condensed tannins, leading to larger amounts of acetaldehyde being produced (Vivas \& Glories, 1996). Du Toit et al. (2006) also found that (+)-catechin levels decreased more in Pinotage wines stored for 24 weeks in new oak barrels than if the wines were aged with oak staves in combination with micro-oxygenation. The trend for stave-treated wines is less clear. Reactions involving monomeric anthocyanins were clearly slowed down or stopped after 15 weeks of maturation, as indicated by the stabilisation of the monomeric anthocyanin content, although the reasons for this are not known. Similar results would be expected for the maturation of wine using staves and chips in old barrels. The different trends could be the result of the extraction rate of oak wood components as affected by the difference in surface to volume ratio of these oak products.

The increased gallic acid content of oak-matured wine, which was observed for Pinotage wine in the present study, supports previous reports on maturation in oak barrels and in stainless steel tanks with oak chips and exogenous tannin additions (Jindra \& Gallander, 1987; Wilker \& Gallander, 1988; Keulder, 2006). This phenomenon can be ascribed to gallic acid formation by the hydrolysis of ellagitannins from oak wood in a hydroalcoholic medium such as wine (Quinn \& Singleton, 1985), or by the hydrolysis of galloylated flavan-3-ols extracted from grape seeds during fermentation (Singleton \& Trousdale, 1983). The latter mechanism is the reason for increases in gallic acid content after maturation in stainless steel, which are less than for wine matured using oak.

Maturation caused a slight decrease in the total phenol content of the Pinotage wine for some of the treatments, similar to what has been found for Pinotage and Cabernet Sauvignon wines subjected to bottle ageing for one year (De Beer et al., 2005). Many individual phenolic compounds also decreased during maturation. The total number of hydroxyl groups does not change much during direct and acetaldehyde-mediated condensation of anthocyanins with flavan-3-ols (Monagas et al., 2005). Despite no changes in the number of hydroxyl groups, they may be less available for reaction with the Folin-Ciocalteu reagent due to steric hindrance. New pigments formed during maturation will be included in the total phenol content, as they react with the Folin-Ciocalteu reagent.

Oak maturation using traditional treatments, as well as alternative oak treatments applied in old barrels was not detrimental to the $\mathrm{TAC}_{\mathrm{M}}$ of Pinotage wine, despite the fact that the $\mathrm{TAC}_{\mathrm{CAL}}$ decreased due to a decrease in many individual monomeric phenolic compounds. The same was true for maturation in stainless steel. The increase in $\mathrm{TAC}_{\mathrm{R}}$ of the wine, which can be ascribed to the formation of new anthocyanin-derived compounds retaining some or all of the antioxidant capacity of the original compounds, counteracted the decrease in $\mathrm{TAC}_{\mathrm{CAL}}$. The same principles as described for the reaction of phenolic compounds with the FolinCiocalteu reagent apply for their reaction with $\mathrm{ABTS}^{\cdot+}$. Although no differences in coloured and non-coloured polymer content were observed, smaller polymers not detected using the current HPLC method are likely to increase in content, contributing to the increased $\mathrm{TAC}_{\mathrm{R}}$. Ellagitannins, which were not measured in the present study, are also likely to contribute to the increased $T_{A C}$ during oak maturation due to their extraction from the oak wood. Ellagitannins have been shown to have high radical scavenging activity (Saint-Cricq de Gaulejac et al., 1998), while the hydrolysis products of ellagitannins, namely ellagic acid (Ivekovic et al., 2005) and gallic acid (Jordão et al., 2005), are also potent antioxidants due to the many available hydroxyl groups. Ellagic tannins are extracted rapidly into a hydro-alcoholic medium, such as wine, followed by a gradual decrease (Jordão et al., 2005). Changes in other unknown compounds, which are not necessarily phenolic in nature but have been shown to make a large contribution to the wine $\mathrm{TAC}_{\mathrm{M}}$ (De Beer et al., 2006), cannot be estimated, but contribute to the $\mathrm{TAC}_{\mathrm{R}}$ of the wine. The role of synergism can also not be ignored (De Beer et al., 2006).

An initial increase in $\mathrm{TAC}_{\mathrm{M}}$ observed for wines treated with new barrels, oak extract and oak dust can be ascribed to compounds extracted from the new oak wood or present in the oak preparations before substantial losses of wine phenolic compounds have occurred, as discussed above. A similar result was obtained by Del Álamo et al. (2006) when measuring the redox potential of wine matured in new barrels and in stainless steel tanks with chips and staves added. In another study, Dávalos et al. (2004) found an increased ORAC value for wines aged in French and American oak barrels compared to bottle-aged wines. The wines that were compared were of the same variety and vintage, but it seems that they were not prepared from the same batch of grapes. Although no detrimental effect on the TAC of the wine was observed in the present study, maturation over a longer period or in the presence of higher oxygen concentrations may have a negative impact on the wine TAC. The maturation of Pinotage and Cabernet Sauvignon wines that were not matured in oak resulted in decreased wine TAC over a one-year bottle-ageing period (De Beer et al., 2005).

The $C^{*}$ and $a^{*}$ values of the Pinotage wine increased initially, followed by a decrease after six weeks of oak maturation. Using the same wines, a similar trend was observed by Fourie (2005) for the modified colour density $\left(\mathrm{OD}_{520}+\mathrm{OD}_{420}\right.$ in the presence of acetaldehyde at $\mathrm{pH} 3.5$ ) of the wine, while the modified degree of red pigment $\left(\mathrm{OD}_{520}\right.$ in the presence of acetaldehyde at $\mathrm{pH} 3.5 \mathrm{x}$ $100 / \mathrm{OD}_{520}$ at low $\mathrm{pH}$ ) showed an increase over the whole maturation period. Pomar and Gonzalez-Mendoza (2001) also observed 
an initial increase in colour density up to three months, followed by a decrease during oak maturation, while only decreases in colour intensity have been reported by others after eight and 12 months of oak maturation (Gómez-Cordovés \& González-SanJosé, 1995; Pérez-Magariño \& González-San José, 2006.). It is important to note that the evolution of wine colour will depend on the initial composition of the wine, especially the anthocyanin content. A decrease in the monomeric pigment content partly explains the reduced $C^{*}$ and $a^{*}$ values of matured wines compared to the control wine (0 weeks). Lower co-pigment content (flavonols, phenolic acids and flavan-3-ols) also contributes to this trend (Gonnet, 1999). On the other hand, monomeric anthocyanins become part of colour-stable oligomeric and polymeric compounds, counteracting the decrease in $C^{*}$, which is the reason for only a modest decrease in $C^{*}$ despite substantial decreases in the content of monomeric pigments and co-pigments. The trend for wine matured in stainless steel differs from that of the oak-matured wines. This may be due to less of a reduction in co-pigment content (phenolic acids and flavan-3-ols).

The present study confirms the finding of Fourie (2005) for wine hue, namely an increase in modified wine hue $\left(\mathrm{OD}_{420}\right.$ in the presence of acetaldehyde at $\mathrm{pH} 3.5 / \mathrm{OD}_{520}$ at low $\mathrm{pH}$ ) during oak maturation. The observed increase in $h^{*}$ indicates a change from magenta-red hues in the direction of orange-red hues, due to decreased $a^{*}$ values and increased $b^{*}$ values, although the wine hues after 28 weeks of maturation were still in the pure red range. Similar trends were also found by Rivas et al. (2006). Some treatments, namely those with staves, oak extract and oak dust, initially caused slight changes in $h^{*}$ towards magenta red. This initial decrease in $h^{*}$ can be ascribed to the formation of purple acetaldehyde-mediated condensation products (Timberlake \& Bridle, 1976; Rivas-Gonzalo et al., 1995). The subsequent increase in $h^{*}$ is attributed to the formation of orange-red pyranoanthocyanins (Fulcrand et al., 1996; 1998) or further reaction of ethyl-linked pigments to form larger, brown polymers (Es-Safi et al., 1999a) or yellow xanthylium pigments (Es-Safi et al., 1999b). Alcalde-Eon et al. (2006) reported an increase in pyranoanthocyanin content in Tempranillo wine during oak maturation (six months) and the subsequent period of bottle ageing. No changes in vitisin A content were observed in the present study, although the content of other pyranoanthocyanins, which were not detected using HPLC, could have increased. The decrease in ethyl-linked pigments observed previously confirms the unstable nature of these pigments.

The wines also became darker (lower $L^{*}$ ) after maturation, in contrast to the finding of Rivas et al. (2006). Generally, the $L^{*}$ and $C^{*}$ values of an anthocyanin solution would increase and decrease respectively with decreased pigment content and/or co-pigmentation. The $L^{*}$ values, however, showed the opposite trend, namely decreasing as the $C^{*}$ values increased. This trend could not be explained by the decrease in monomeric pigment and co-pigment content. In the same way as for $C^{*}$, the increase in oligomeric and polymeric pigments would contribute to a decrease in $L^{*}$. In this case it seems that the effect of polymerisation on the $C^{*}$ and $L^{*}$ values differed. This is possibly due to the formation of brown polymers during maturation, contributing to a decrease in $L^{*}$ without increasing $C^{*}$.

The treatment in new barrels had the greatest effect on the objective colour parameters $\left(C^{*}, h^{*}, L^{*}\right.$ and $\left.b^{*}\right)$ of the wine, with few significant differences between the other treatments after 28 weeks of maturation. This result is similar to the trends observed by Fourie (2005) and Van Rensburg and Joubert (2002). The pronounced effect of new-barrel treatment on Pinotage wine is explained by the fact that the pigment content, as well as the co-pigment content, of wines treated in new barrels showed more pronounced changes after maturation than the other treatments.

Taking the sensory characteristics of the wines (Fourie, 2005) and the objective colour measurements into account, wine treated in new barrels overall was of a better quality than that from the other treatments. The treatment with chips resulted in wine with decreased sensory quality. The other alternative oak products, however, gave wines with good sensory quality.

Canonical discriminant analysis confirmed the observation that the wines treated in new barrels and with staves differed significantly from the other wine, especially on completion of maturation. The differences between the control wines and the other wines were also highlighted.

In conclusion, alternative oak products show potential for producing Pinotage wines with good colour and sensory quality. Oak maturation using traditional and alternative oak products maintained the TAC of Pinotage wine, despite significant changes in its phenolic composition. It therefore is a good technique for producing quality red wines while retaining the TAC of the wine. The changes in phenolic composition during maturation towards more oligomeric and polymeric compounds, which are less bioavailable, have implications for the potential in vivo bioactivity of red wine.

\section{ABBREVIATIONS}

ac = acetate; control wine $(0$ weeks $)=$ non-matured wine; control wine $(\mathrm{SS})=$ wine matured in stainless steel canisters for 28 weeks; coum = coumarate; gal = galactoside; glc = glucoside; rham $=$ rhamnoside; $\mathrm{TAC}=$ total antioxidant capacity; $\mathrm{TAC}_{\mathrm{M}}=\mathrm{TAC}$ as measured; $\mathrm{TAC}_{\mathrm{CAL}}=\mathrm{TAC}$ as calculated from phenolic composition and TEAC values; $\mathrm{TAC}_{\mathrm{R}}=\mathrm{TAC}$ remaining after $\mathrm{TAC}_{\mathrm{CAL}}$ is subtracted from $\mathrm{TAC}_{\mathrm{M}} ; \mathrm{TE}=$ Trolox equivalents; $\mathrm{TEAC}=$ Trolox equivalent antioxidant capacity

\section{LITERATURE CITED}

Alcalde-Eon, C., Escribano-Bailón, M.T., Santos-Buelga, C. \& Rivas-Gonzalo, J.C., 2006. Changes in the detailed pigment composition of red wine during maturity and ageing. A comprehensive study. Anal. Chim. Acta 563, 238-254.

Castellari, M., Simonato, B., Tornielli, G.B., Spinelli, P. \& Ferrarini, R., 2004. Effects of different enological treatments on dissolved oxygen in wines. Ital. J. Food Sci. 16, 387-397

Cheynier, V., Osse, C. \& Rigaud, J., 1988. Oxidation of grape juice phenolic compounds in model solutions. J. Food Sci. 53, 1729-1732.

Dávalos, A., Gómez-Cordovés, C. \& Bartolomé, B., 2004. Extending applicability of the oxygen radical absorbance capacity (ORAC-fluorescein) assay. J. Agric. Food Chem. 52, 48-54.

De Beer, D., Joubert, E., Gelderblom, W.C.A. \& Manley, M., 2005. Changes in the phenolic composition and antioxidant activity of Pinotage, Cabernet Sauvignon, Chardonnay and Chenin blanc wines during bottle ageing. S. Afr. J. Enol. Vitic. 26, 6-15.

De Beer, D., Joubert, E., Marais, J. \& Manley, M., 2006. Unravelling the total antioxidant capacity of Pinotage wines: contribution of phenolic compounds. J. Agric. Food Chem. 54, 2897-2905.

Del Álamo, M., Nevares, I. \& Cárcel, L.M., 2006. Redox potential evolution during red wine aging in alternative systems. Anal. Chim. Acta 563, 223-228. 
Del Alamo Sanza, M., Domínguez, I N., Cárcel Cárcel, L.M. \& Gracia, L.N., 2004. Analysis for low molecular weight phenolic compounds in a red wine aged in oak chips. Anal. Chim. Acta 513, 229-237.

Es-Safi, N.-E., Fulcrand, H., Cheynier, V. \& Moutounet, M., 1999a. Studies on the acetaldehyde-induced condensation of (-)-epicatechin and malvidin-3-O-glucoside in a model solution system. J. Agric. Food Chem. 47, 2096-2102.

Es-Safi, N.-E., Fulcrand, H., Cheynier, V. \& Moutounet, M., 1999b. Competition between (+)-catechin and (-)-epicatechin in acetaldehyde-induced polymerization of flavanols. J. Agric. Food Chem. 47, 2088-2095.

Fourie, B., 2005. The influence of barrel type, oak blocks, oak tannins and oak powder on the composition and quality of red wine. Thesis, Stellenbosch University, Private Bag X1, 7602 Matieland (Stellenbosch), South Africa.

Fulcrand, H., Cameira dos Santos, P.J., Sarni-Manchado, P., Cheynier, V. \& FavreBonvin, J., 1996. Structure of new anthocyanin-derived wine pigments. J. Chem. Soc., Perkin Trans. 1, 735-739.

Fulcrand, H., Benabdeljalil, C., Rigaud, J., Cheynier, V. \& Moutounet, M., 1998. A new class of wine pigments generated by reaction between pyruvic acid and grape anthocyanins. Phytochem. 47, 1401-1407.

Fulcrand, H., Atanasova, V., Salas, E. \& Cheynier, V., 2004. The fate of anthocyanins in wine: are there determining factors? In: Waterhouse, A.L. \& Kennedy, J.A. (eds). Red wine color: revealing the mysteries, ACS Symposium Series 886 . ACS, Washington, DC.

Gómez-Cordovés, C. \& González-SanJosé, M.L., 1995. Interpretation of color variables during the aging of red wines: relationship with families of phenolic compounds. J. Agric. Food Chem. 43, 557-561.

Gonnet, J.-F., 1999. Color effects of co-pigmentation of anthocyanins revisited. 2. A colorimetric look at the solutions of cyanin co-pigmented by rutin using the CIELAB scale. Food Chem. 66, 387-394.

Hernández, T., Estrella, I., Carlavilla, D., Martín-Álvarez, P.J. \& Moreno-Arribas, M.V., 2006. Phenolic compounds in red wine subjected to industrial malolactic fermentation and ageing on lees. Anal. Chim. Acta 563, 116-125.

Ivekovic, D., Milardovic, S., Roboz, M. \& Grabaric, B.S., 2005. Evaluation of the antioxidant activity by flow injection analysis method with electrochemically generated ABTS radical cation. Analyst 130, 708-714.

Jindra, J.A. \& Gallander, J.F., 1987. Effect of American and French oak barrels on the phenolic composition and sensory quality of Seyval blanc wines. Am. J. Enol. Vitic. 38, 133-138.

Jordão, A.M., Ricardo da Silva, J.M. \& Laureano, O., 2005. Extraction of some ellagic tannins and ellagic acid from oak wood chips (Ouercus pyrenaica L.) in model wine solutions: effect of time, $\mathrm{pH}$, temperature and alcoholic contents. S. Afr. J. Enol. Vitic. 26, 83-89.

Kadim, D. \& Mannheim, C.H., 1999. Kinetics of phenolic extraction during aging of model wine solution and white wine in oak barrels. Am. J. Enol. Vitic. 50, 33-39.

Keulder, D.B., 2006. The influence of commercial tannin additions on wine composition and quality. Thesis, Stellenbosch University, Private Bag X1, 7602 Matieland (Stellenbosch), South Africa.

Laszlavik, M., Gál, L., Misik, S. \& Erdei, L., 1995. Phenolic compounds in two Hungarian red wines matured in Quercus robur and Quercus petraea barrels: HPLC analysis and diode array detection. Am. J. Enol. Vitic. 46, 67-74.

Monagas, M., Bartolomé, B. \& Gomez-Cordoves, C., 2005. Updated knowledge about the presence of phenolic compounds in wine. Crit. Rev. Food Sci. Nutr. 45, 85-118.
Peng, Z., Iland, P., Oberholster, A., Sefton, M.A. \& Waters, E.J., 2002. Analysis of pigmented polymers in red wine by reversed phase HPLC. Aust. J. Grape Wine Res. 8, 70-75.

Pérez-Magariño, S. \& González-San José, M.L., 2006. Polyphenols and color variability of red wines made from grapes harvested at different ripeness grade. Food Chem. 96, 197-208.

Pomar, M. \& Gonzalez-Mendoza, L.A., 2001. Changes in composition and sensory quality of red wine aged in American and French oak barrels. J. Int. Sci. Vigne Vin 35, 41-48.

Quinn, M.K. \& Singleton, V.L., 1985. Isolation and identification of ellagitannins from white oak wood and an estimation of their roles in wine. Am. J. Enol. Vitic. $36,148-155$.

Re, R., Pellegrini, N., Proteggente, A., Pannala, A., Yang, M. \& Rice-Evans, C.A., 1999. Antioxidant activity applying an improved ABTS radical cation assay. Free Radical Biol. Med. 26, 1231-1237.

Rigaud, J., Cheynier, V., Souquet, J.M. \& Moutounet, M., 1991. Influence of must composition on phenolic oxidation kinetics. J. Sci. Food Agric. 57, 55-63.

Rivas, E.G.-P., Alcalde-Eon, C., Santos-Buelga, C., Rivas-Gonzalo, J.C. \& Escribano-Bailón, M.T., 2006. Behaviour and characterisation of the color during red wine making and maturation. Anal. Chim. Acta 563, 215-222.

Rivas-Gonzalo, J.C., Bravo-Haro, S. \& Santos-Buelga, C., 1995. Detection of compounds formed through the reaction of malvidin-3-monoglucoside and catechin in the presence of acetaldehyde. J. Agric. Food Chem. 43, 1444-1449.

Saint-Cricq de Gaulejac, N., Glories, Y. \& Vivas, N., 1998. Determination of the compounds responsible for the anti-radical effect of wines. The influence of maturing in barrels. J. Sci. Tech. Tonnelerie 4, 163-177.

Singleton, V.L., 1987. Oxygen with phenols and related reactions in musts, wines, and model systems: observations and practical implications. Am. J. Enol. Vitic. $38,69-77$.

Singleton, V.L. \& Rossi, J.R., 1965. Colorimetry of total phenols with phosphomolybdic-phosphotungstic acid reagents. Am. J. Enol. Vitic. 16, 144-158.

Singleton, V.L., Salgues, M., Zaya, J. \& Trousdale, E., 1985. Caftaric acid disappearance and conversion to products of enzymic oxidation in grape must and wine. Am. J. Enol. Vitic. 36, 50-56.

Singleton, V.L. \& Trousdale, E., 1983. White wine phenolics: varietal and processing differences as shown by HPLC. Am. J. Enol. Vitic. 34, 27-34.

Timberlake, C.F. \& Bridle, P., 1976. Interactions between anthocyanins, phenolic compounds, and acetaldehyde and their significance in red wines. Am. J. Enol. Vitic. 27, 97-105.

Van Rensburg, P. \& Joubert, J., 2002. Introductory study on the use of alternative wood maturation methods. Wynboer 156, 88-91.

Vivas, N. \& Glories, Y., 1996. Role of oak wood ellagitannins in the oxidation process of red wines during aging. Am. J. Enol. Vitic. 47, 103-107.

Wildenradt, H.L. \& Singleton, V.L., 1974. The production of aldehydes as a result of oxidation of polyphenolic compounds and its relation to wine ageing. Am. J. Enol. Vitic. 25, 119-126.

Wilker, K.L. \& Gallander, J.F., 1988. Comparison of Seyval blanc wine aged in barrels and stainless steel tanks with oak chips. Am. J. Enol. Vitic. 39, 38-43. 